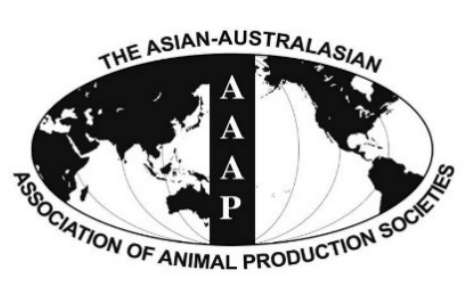

Open Access

Asian Australas. J. Anim. Sci.

Vol. 29, No. 11 : 1569-1575 November 2016

http://dx.doi.org/10.5713/ajas.16.0162

www.ajas.info

pISSN 1011-2367 elSSN 1976-5517

\title{
Influence of Kaolinite Clay Supplementation on Growth Performance and Digestive Function in Finishing Calf-fed Holstein Steers
}

\author{
José Ortiz ${ }^{1}$, Martín Montaño ${ }^{1}$, Alejandro Plascencia ${ }^{1, *}$, Jaime Salinas ${ }^{2}$, \\ Noemí Torrentera ${ }^{1}$, and Richard A. Zinn \\ Department of Animal Science, University of California, Davis, CA 95616, USA
}

\begin{abstract}
Two experiments were conducted to examine the influence of kaolinite clay supplementation $(0 \%, 1 \%$, or $2 \%$ diet dry matter [DM] basis) on characteristics of digestion (Trial 1) and growth performance (Trial 2) in calf-fed Holstein steers fed a finishing diet. In Trial 1, 6 Holstein steers $(539 \pm 15 \mathrm{~kg})$ with ruminal and duodenal cannulas were used to evaluate treatment effects on characteristics of digestion. Kaolinite clay supplementation decreased total tract DM digestion (linear effect, $p<0.01$ ) without effects $(p \geq 0.10)$ on site and extent of digestion of organic matter, neutral detergent fiber, starch and $\mathrm{N}$, or ruminal microbial efficiency. There were no treatment effects on ruminal $\mathrm{pH}$, volatile fatty acids molar proportions or estimated methane production. In Trial 2, 108 Holstein steers $(132.4 \pm 5.6 \mathrm{~kg})$ were used in a 308-d study to evaluate growth performance and carcass characteristics. There were no treatment effects $(p>0.10)$ on average daily gain (ADG) and gain efficiency (ADG/dry matter intake). Kaolinite supplementation tended (linear effect, $p=0.08)$ to increase dietary net energy (NE) during the initial 112-d period. However, the overall (308-d) effect of supplementation dietary NE was not appreciable $(\mathrm{p}>0.20)$. However, due to the inertness of kaolinite, itself, the ratio of observed-to-expected dietary NE increased with kaolinite supplementation. This effect was more pronounced (linear effect, $\mathrm{p} \leq 0.03$ ) during the initial $224 \mathrm{~d}$ of the study. Overall ( $308 \mathrm{~d}$ ), kaolinite supplementation tended to increase (linear effect, $\mathrm{p}=0.07$ ) dietary NE by $3 \%$ over expected. Kaolinite supplementation did not affect carcass weight, yield grade, longissimus area, kidney, pelvic and heart fat, and quality grade, but decreased (linear effect, $\mathrm{p}=0.01$ ) dressing percentage. It is concluded that kaolinite supplementation up to $2 \%$ of diet DM may enhance energetic efficiency of calf-fed Holstein steers in a manner independent of changes in characteristics of ruminal and total tract digestion. (Key Words: Kaolinite, Feedlot, Supplementation, Cattle, Growth, Digestion)
\end{abstract}

\section{INTRODUCTION}

Clay minerals (bentonite, kaolinite, zeolite) are ubiquitous in nature. Unique structural properties lend to their usefulness as feed additives. Zeolites are a family of minerals of volcanic origin that are composited of crystalline aluminosilicates. Their dimensional structures are characterized by an ability to lose and gain water reversibly and to exchange cations without major change of their

\footnotetext{
* Corresponding Author: Alejandro Plascencia. Tel: $+52-686-563$ 6906(111), Fax: +52-686-5636907, E-mail: aplas_99@yahoo.com ${ }^{1}$ Instituto de Investigaciones en Ciencias Veterinarias, UABC, Mexicali, Baja California 21380, México.

${ }^{2}$ Facultad de Medicina Veterinaria y Zootecnia UAT, Cd. Victoria, Tamaulipas 87000, México.

Submitted Feb. 27, 2016; Revised Apr. 12, 2016; Accepted Apr. 18, 2016
}

structure (Trckova et al., 2004). Bentonite and kaolinite clay (or kaolin) on the other hand, are members of phillosilicates. Bentonite is a rock constituted of highly colloidal plastic clays composed mainly by montmorillonite (Safaei et al., 2014). The particular characteristic of bentonite is its capability to form gel with water and its high cation exchange capacity (about half the CEC of zeolite clay). Kaolinite is formed by the weathering of aluminous minerals such a feldspar, a plastic clay mineral (Owen et al., 2012), kaolinite has a low shrink-swell capacity and a low cation-exchange capacity ( 1 to $15 \mathrm{meq} / 100 \mathrm{~g}$ ). Recognized as safe for feeding to livestock (EFSA, 2016), kaolinite is widely used as a binder for pelleted feeds, for anti-caking, as an anti-diarrheal and for aflatoxin reduction (Spotti et al., 2005). Due to its chemical, and antimicrobials properties, kaolinite supplementation has been shown to also enhance average 
daily gain (ADG), feed efficiencies, and carcass yields in non-ruminants species (Trckova et al., 2004). However, very little work has been reported that evaluates the effects of kaolinite supplementation on growth-performance of feedlot cattle is limited. The objective of this experiment was to examine the influence of kaolinite clay supplementation $(0 \%$, $1 \%$, or $2 \%$ diet dry matter [DM] basis) on characteristics of digestion, feedlot growth performance and carcass characteristics of calf-fed Holstein steers fed a steam-flaked corn-based diet.

\section{MATERIALS AND METHODS}

All procedures involving animal care and management were in accordance with and approved by the University of California, Davis, Animal Use and Care Committee.

\section{Trial 1: Characteristics of digestion and ruminal fermentation}

Animals, sampling and treatments: Six Holstein steers $(539 \pm 15 \mathrm{~kg})$ with cannulas in the rumen $(3.8 \mathrm{~cm}$ internal diameter) and proximal duodenum were used in a replicated $3 \times 3$ Latin square experiment to study treatment effects on characteristics of digestion. Dietary treatments consisted of a steam-flaked corn-based growing-finishing diet supplemented (diet DM basis) with $0 \%, 1 \%$, or $2 \%$ of kaolinite clay (Ione Minerals Inc., Ione, CA, USA). Composition of experimental diets is shown in Table 1. Chromic oxide ( $3.0 \mathrm{~g} / \mathrm{kg}$ of diet air-dry basis) was used as an indigestible marker to estimate nutrient flow and digestibility. Steers were maintained in individual pens $\left(4 \mathrm{~m}^{2}\right)$ with automatic waterers. Diets were fed at 0800 and $2000 \mathrm{~h}$ daily. In order to avoid feed refusals, dry matter intake (DMI) was restricted to $10.3 \mathrm{~kg} / \mathrm{d}$ (equivalent to $1.9 \%$ of live weight $[\mathrm{LW}])$. Experimental periods consisted of a 10-d diet adjustment period followed by a 4-d collection period. Between each experimental period, steers were allowed a 7$\mathrm{d}$ recovery period during which all steers were fed the control diet. During collection, duodenal and fecal samples were taken twice daily as follows: $\mathrm{d}$ 1, 0750 and $1350 \mathrm{~h} ; \mathrm{d}$ 2, 0900 and $1500 \mathrm{~h} ; \mathrm{d} 3,1050$ and $1650 \mathrm{~h}$, and d 4, 1200 and $1800 \mathrm{~h}$. Individual samples consisted of approximately $700 \mathrm{~mL}$ of duodenal chime and $200 \mathrm{~g}$ (wet basis) of fecal material. Samples from each steer within each collection period were composited for analysis. During the final day of each collection period, ruminal samples were obtained from each steer via ruminal cannula $4 \mathrm{~h}$ after feeding. Ruminal fluid $\mathrm{pH}$ was determined on fresh samples. Samples were strained through 4 layers of cheesecloth. Two milliliters of freshly prepared $25 \%(\mathrm{wt} / \mathrm{vol})$ meta-phosphoric acid was added to 8 $\mathrm{mL}$ of strained ruminal fluid. Samples were then centrifuged $(17,000 \times g$ for $10 \mathrm{~min})$, and supernatant fluid was stored at $20^{\circ} \mathrm{C}$ for volatile fatty acids (VFA) analysis by gas
Table 1. Composition of experimental diets fed to steers (DM basis)

\begin{tabular}{|c|c|c|c|}
\hline \multirow{2}{*}{ Item } & \multicolumn{3}{|c|}{ Kaolinite level (\%) } \\
\hline & 0 & 1 & 2 \\
\hline \multicolumn{4}{|l|}{ Ingredient composition (\%) } \\
\hline Steam-flaked corn & 67.53 & 66.53 & 65.53 \\
\hline Distillers dried grains plus solubles & 10.00 & 10.00 & 10.00 \\
\hline Sudan grass hay & 12.00 & 12.00 & 12.00 \\
\hline Molasses cane & 4.00 & 4.00 & 4.00 \\
\hline Yellow grease & 3.00 & 3.00 & 3.00 \\
\hline Urea & 1.20 & 1.20 & 1.20 \\
\hline Limestone & 1.80 & 1.80 & 1.80 \\
\hline Magnesium oxide & 0.15 & 0.15 & 0.15 \\
\hline Trace mineral salt ${ }^{1}$ & 0.30 & 0.30 & 0.30 \\
\hline Kaolinite clay & - & 1.00 & 2.00 \\
\hline Monensin $(\mathrm{g} / \mathrm{T})$ & 35.00 & 35.00 & 35.00 \\
\hline \multicolumn{4}{|l|}{ Nutrient composition (DM basis) ${ }^{2}$} \\
\hline \multicolumn{4}{|l|}{ Net energy (Mcal/kg) } \\
\hline Maintenance & 2.21 & 2.19 & 2.17 \\
\hline Gain & 1.54 & 1.53 & 1.51 \\
\hline Crude protein $(\%)$ & 14.0 & 13.9 & 13.8 \\
\hline Calcium (\%) & 0.79 & 0.79 & 0.80 \\
\hline Phosphorus (\%) & 0.34 & 0.33 & 0.33 \\
\hline Potassium (\%) & 0.75 & 0.75 & 0.74 \\
\hline Magnesium (\%) & 0.29 & 0.29 & 0.29 \\
\hline Sulfur (\%) & 0.16 & 0.16 & 0.16 \\
\hline
\end{tabular}

DM, dry matter.

${ }^{1}$ Trace mineral salt contained (\%): $\mathrm{CoSO}_{4}, 0.068 ; \mathrm{CuSO}_{4}, 1.04 ; \mathrm{FeSO}_{4}$, 3.57; $\mathrm{ZnO}, 1.24 ; \mathrm{MnSO}_{4}, 1.07$; KI, 0.052; $\mathrm{NaCl}, 92.96$.

${ }^{2}$ Based on tabular values for individual feed ingredients (NRC,1996).

chromatograph. Upon completion of the experiment, ruminal fluid was obtained via the ruminal cannula from all steers and composited for isolation of ruminal bacteria by differential centrifugation (Bergen et al., 1968).

Sample analysis and calculations: Feed, duodenal and fecal samples were subject to the following analysis: DM (oven drying at $105^{\circ} \mathrm{C}$ until no further weight loss; method 930.15; AOAC, 2000); ash (method 942.05; AOAC, 2000), Kjeldahl N (method 984.13; AOAC, 2000); aNDFom [Van Soest et al., 1991, corrected for neutral detergent fiber (NDF)-ash, incorporating heat stable $\alpha$-amylase (Ankom Technology, Macedon, NY, USA) at $1 \mathrm{~mL}$ per $100 \mathrm{~mL}$ of NDF solution (Midland Scientific, Omaha, NE, USA)]; chromic oxide (Hill and Anderson, 1958), and starch (Zinn, 1990). Microbial organic matter (OM) and nitrogen leaving the abomasum were calculated using purines as a microbial marker (Zinn and Owens, 1986). The OM fermented in the rumen was considered equal to $\mathrm{OM}$ intake minus the difference between the amount of total OM reaching the duodenum and microbial OM reaching the duodenum. Feed $\mathrm{N}$ escape to the small intestine was considered equal to total $\mathrm{N}$ leaving the abomasum minus ammonia- $\mathrm{N}$, microbial $\mathrm{N}$ 
(MN) and endogenous $\mathrm{N}$, assuming endogenous $\mathrm{N}$ is equivalent to $0.195 \mathrm{~W}^{0.75}$ (Orskov et al., 1986). Ruminal microbial efficiency was estimated as duodenal $\mathrm{MN}, \mathrm{g} / \mathrm{kg}$ $\mathrm{OM}$ fermented in the rumen and $\mathrm{N}$ efficiency represent the duodenal non-ammonia N, g/g N intake. Methane production (mol/mol glucose equivalent fermented) was estimated based on the theoretical fermentation balance for observed molar distribution of VFA (Wolin, 1960).

Statistical design and analysis: Treatment effects on characteristics of digestion in cattle were analyzed as a replicated $3 \times 3$ Latin square design using the MIXED procedure (SAS Inst. Inc., Cary, NC, USA). Treatments effects on digestion and fermentation variables were tested by means of polynomial contrasts (SAS Inst.; Version 9.3). Contrasts were considered significant when the $\mathrm{p}$-value was $\leq 0.05$, and tendencies were identified when the $p$-value was $>0.05$ and $\leq 0.10$.

Trial 2: Growth performance and carcass characteristics Animals and diets: One hundred eight Holstein steers $(132.4 \pm 5.6 \mathrm{~kg})$ were used in a 308 -d experiment to evaluate the influence of kaolinite clay supplementation on growth performance, dietary net energy (NE), and carcass characteristics. Cattle originated from Tulare, California, and were received at the University of California Desert Research Center, El Centro, on April 29, 2014. Upon arrival, steers were treated for parasites (Dectomax Injectable, Zoetis, New York, NY, USA), and injected subcutaneously with tuluthramycin (Draxxin, Pfizer, New York, NY, USA), and 500,000 IU vitamin A (Vital E-A+D, Stuart Products, Bedford, TX, USA). Steers were balanced by weight and assigned within weight groupings to 18 pens (6 steers/pen). Pens were $78 \mathrm{~m}^{2}$ with $33 \mathrm{~m}^{2}$ of overhead shade, automatic waterers, and fence-line feed bunks. Dietary treatments were the same as in Trial 1. Composition of experimental diets is shown in Table 1. Diets were prepared at weekly intervals and stored in plywood boxes located in front of each pen. Steers were allowed ad libitum access to their experimental diets. Fresh feed was provided twice daily. On day 112 and 224, all steers were injected subcutaneously with 500,000 IU vitamin A (Vital E-A+D, Stuart Products, USA) and implanted with Revalor-S (Intervet, Millsboro, DE, USA).

Estimation of dietary net energy: For calculating steer performance measures of live weight were reduced $4 \%$ to account for digestive tract fill. Final shrunk LW was carcassadjusted by dividing hot carcass weights (HCW) by the decimal fraction of the average dressing percentage (0.618). Daily energy gain (EG; Mcal/d) was calculated by the equation: $\mathrm{EG}=\mathrm{ADG}^{1.097} 0.0557 \mathrm{~W}^{0.75}$, where $\mathrm{W}$ is the mean shrunk weight (kg; NRC, 1984). Maintenance energy (EM) was calculated by the equation: $\mathrm{EM}=0.084 \mathrm{~W}^{0.75}$ (Garrett, 1971). Dietary net energy for gain $\left(\mathrm{NE}_{\mathrm{g}}\right)$ was derived from net energy for maintenance $\left(\mathrm{NE}_{\mathrm{m}}\right)$ by the equation: $\mathrm{NE}_{\mathrm{g}}=$ $0.877 \mathrm{NE}_{\mathrm{m}}-0.41$ (Zinn et al., 2008). DMI is related to energy requirements and dietary $\mathrm{NE}_{\mathrm{m}}$ according to the equation: $\mathrm{DMI}=\mathrm{EG} /\left(0.877 \mathrm{NE}_{\mathrm{m}}-0.41\right)$, and can be resolved for estimation of dietary NE by means of the quadratic formula: $x=\left(-\mathrm{b}-\sqrt{ } \mathrm{b}^{2}-4 \mathrm{ac}\right) / 2 \mathrm{c}$, where: $x=\mathrm{NE}_{\mathrm{m}}, \mathrm{a}=-0.42 \mathrm{EM}, \mathrm{b}=$ $0.887 \mathrm{EM}+0.41 \mathrm{DMI}+\mathrm{EG}$, and $\mathrm{c}=-0.887 \mathrm{DMI}$ (Zinn et al., 2008).

Carcass data: The HCW were obtained at time of slaughter. After carcasses chilled for $48 \mathrm{~h}$, the following measurements were obtained: Longissimus (LM) area $\left(\mathrm{cm}^{2}\right)$ by direct grid reading of the muscle at the 12th rib; subcutaneous fat $(\mathrm{cm})$ over the LM at the 12 th rib taken at a location $3 / 4$ the lateral length from the chine bone end (adjusted by eye for unusual fat distribution); kidney, pelvic and heart fat $(\mathrm{KPH})$ as a percentage of $\mathrm{HCW}$; marbling score (USDA, 1997; using 3.0 as minimum slight, 4.0 as minimum small, 5.0 as minimum modest, 6.0 as minimum moderate, etc.), and estimated retail yield of boneless, closely trimmed retail cuts from the round, loin, rib and chuck (\% of $\mathrm{HCW}$; Murphey et al., 1960) $=52.56-1.95 \times$ subcutaneous fat$1.06 \times \mathrm{KPH}+0.106 \times \mathrm{LM}$ area $-0.018 \times \mathrm{HCW}$.

Statistical design and analysis: Performance (gain, gain efficiency, and dietary energetics) and carcass data were analysed as a randomised complete block design. The experimental unit was the pen. The MIXED procedure of SAS (SAS Institute, 2004) was used to analyse the variables. The fixed effect consisted of treatment, and pen as the random component. Treatment effects were tested by means of orthogonal polynomials (SAS Inst.; Version 9.3). Contrasts were considered significant when the p-value was $\leq 0.05$, and tendencies were identified when the $\mathrm{p}$-value was $>0.05$ and $\leq 0.10$.

\section{RESULTS AND DISCUSSION}

\section{Trial 1: Characteristics of digestion and ruminal fermentation}

Treatment effects on characteristics of ruminal and total tract digestion of experimental diets are shown in Table 2. There were no treatment effects $(\mathrm{p} \geq 0.10)$ on ruminal microbial efficiency (g MN/kg OM fermented) or ruminal and total tract digestion N. Very limited information has been reported regarding the effects of kaolinite supplementation on site and extent of digestions of steers fed high-grain finishing diets. Previous studies evaluating supplemental zeolite clay at levels comparable to that of the present study (McCollum and Galyean, 1983; Cole et al., 2007) likewise did not show an effect of supplementation on $\mathrm{N}$ digestion in finishing diets fed to cattle.

There were no treatment effects $(\mathrm{p} \geq 0.10)$ on ruminal and total tract digestion of OM, starch and NDF. Because their sorbent properties that increase the ruminal fluid viscosity (Spotti et al., 2005), it has been postulated that inclusion of clay could decrease fluid dilution rate, possibly enhancing 
Table 2. Influence of supplementation level of kaolinite clay on characteristics of apparent ruminal and total tract digestion in Holstein steers

\begin{tabular}{|c|c|c|c|c|c|c|}
\hline \multirow{2}{*}{ Item } & \multicolumn{3}{|c|}{ Kaolinite level (\% diet DM) } & \multirow{2}{*}{ SEM } & \multicolumn{2}{|c|}{ p-value } \\
\hline & 0 & 1 & 2 & & Linear & Quadratic \\
\hline Steer replicates & 6 & 6 & 6 & & & \\
\hline \multicolumn{7}{|l|}{ Intake (g/d) } \\
\hline $\mathrm{DM}$ & 10,278 & 10,278 & 10,278 & & & \\
\hline $\mathrm{OM}$ & 9,606 & 9,606 & 9,605 & & & \\
\hline NDF & 1,595 & 1,661 & 1,728 & & & \\
\hline $\mathrm{N}$ & 213 & 212 & 211 & & & \\
\hline Starch & 5,371 & 5,298 & 5,225 & & & \\
\hline \multicolumn{7}{|c|}{ Flow to duodenum, $\mathrm{g} / \mathrm{d}$} \\
\hline $\mathrm{OM}$ & 5,250 & 5,036 & 5,392 & 151 & 0.53 & 0.16 \\
\hline NDF & 1,059 & 958 & 1,053 & 60 & 0.94 & 0.22 \\
\hline Starch & 955 & 993 & 1123 & 88 & 0.21 & 0.69 \\
\hline Non-ammonia $\mathrm{N}$ & 239 & 235 & 236 & 9.5 & 0.85 & 0.82 \\
\hline Microbial N & 140 & 145 & 141 & 5.6 & 0.85 & 0.59 \\
\hline Feed N & 77 & 68 & 72 & 8.0 & 0.72 & 0.52 \\
\hline \multicolumn{7}{|c|}{ Ruminal digestion (\%) } \\
\hline $\mathrm{OM}$ & 59.91 & 62.64 & 58.57 & 1.50 & 0.54 & 0.10 \\
\hline NDF & 33.26 & 41.99 & 30.31 & 3.48 & 0.25 & 0.22 \\
\hline Starch & 82.22 & 81.27 & 78.55 & 1.65 & 0.15 & 0.67 \\
\hline Feed $\mathrm{N}$ & 64.15 & 68.00 & 65.61 & 3.79 & 0.79 & 0.52 \\
\hline MN efficiency ${ }^{1}$ & 24.47 & 24.19 & 25.29 & 1.23 & 0.65 & 0.66 \\
\hline $\mathrm{N}$ efficiency ${ }^{2}$ & 1.12 & 1.11 & 1.12 & 0.05 & 0.96 & 0.82 \\
\hline \multicolumn{7}{|l|}{ Fecal excretion (g/d) } \\
\hline $\mathrm{DM}$ & 2,392 & 2,648 & 2,684 & 52 & $<0.01$ & 0.12 \\
\hline $\mathrm{OM}$ & 1,969 & 2,099 & 2,096 & 56 & 0.15 & 0.36 \\
\hline NDF & 913 & 972 & 965 & 40 & 0.39 & 0.53 \\
\hline Starch & 86.9 & 83.6 & 88.7 & 16.4 & 0.94 & 0.84 \\
\hline $\mathrm{N}$ & 60.1 & 64.3 & 64.2 & 2.6 & 0.29 & 0.52 \\
\hline \multicolumn{7}{|c|}{ Total tract digestion (\%) } \\
\hline $\mathrm{DM}$ & 76.7 & 74.3 & 73.9 & 0.5 & $<0.01$ & 0.13 \\
\hline $\mathrm{OM}$ & 79.5 & 78.2 & 78.2 & 0.6 & 0.15 & 0.37 \\
\hline NDF & 42.7 & 41.0 & 44.2 & 2.4 & 0.68 & 0.44 \\
\hline Starch & 98.4 & 98.4 & 98.3 & 0.3 & 0.88 & 0.84 \\
\hline $\mathrm{N}$ & 71.8 & 69.7 & 69.5 & 1.2 & 0.21 & 0.53 \\
\hline
\end{tabular}

DM, dry matter; SEM, standard error of the mean; OM, organic matter; NDF, neutral detergent fiber; MN, microbial N.

${ }^{1}$ Microbial nitrogen, $\mathrm{g} / \mathrm{kg}$ organic matter fermented.

${ }^{2}$ Non-ammonia nitrogen flow to the small intestine as a fraction of nitrogen intake.

the extent of ruminal digestion. However, the effect of zeolites and bentonite on ruminal passage rate has been inconsistent (McCollum and Galyean, 1983). Decreased total tract DM digestion with no effect on OM digestion has been reported previously with the inclusion of bentonite in sorghum-based (Martin et al., 1696) and corn silage-based (Ivan et al., 1992) diets. Likewise, Dinius et al. (1970) observed that total tract DM digestion decreased linearly with increasing kaolinite supplementation. Decreased total tract DM digestion with clays supplementation is expected, due to indigestibility of clay, itself.

Kaolinite supplementation did not affect $(p>0.10)$ ruminal $\mathrm{pH}$ (averaging 5.82), VFA molar proportions or estimated methane production. Based on diet formulation, expected ruminal $\mathrm{pH}$ was 5.73 (NRC, 1996), in reasonably good agreement with observed. Tate et al. (2015) likewise did not observe effects of kaolinite supplementation (7.5 and $15 \mathrm{~g} / \mathrm{kg} \mathrm{DM}$ ) on ruminal $\mathrm{pH}$ (determined in vitro). The lack of effects of kaolinite supplementation on ruminal $\mathrm{pH}$ and VFA profiles is consistent with non-appreciable effects on measures of ruminal digestion of $\mathrm{OM}$, starch, NDF, and $\mathrm{N}$ (Table 3).

\section{Trial 2: Growth performance and carcass characteristics}

The effects of kaolinite clay supplementation on 308-d feedlot growth-performance of calf-fed Holstein steers are shown in Table 4 . There were no treatment effects $(p>0.10)$ 
Table 3. Influence of supplementation level of kaolinite clay on ruminal $\mathrm{pH}$, volatile fatty acid profile and estimate methane production

\begin{tabular}{|c|c|c|c|c|c|c|}
\hline \multirow{2}{*}{ Item $^{1}$} & \multicolumn{3}{|c|}{ Kaolinite level (\% diet DM) } & \multirow{2}{*}{ SEM } & \multicolumn{2}{|c|}{ p-value } \\
\hline & 0 & 1 & 2 & & Linear & Quadratic \\
\hline Ruminal pH & 5.87 & 5.74 & 5.86 & 0.09 & 0.94 & 0.30 \\
\hline \multicolumn{7}{|c|}{ Ruminal VFA (mol/100 mol) } \\
\hline Acetate & 53.2 & 50.8 & 50.8 & 1.8 & 0.52 & 0.19 \\
\hline Propionate & 36.6 & 36.6 & 35.8 & 2.8 & 0.83 & 0.91 \\
\hline Butyrate & 10.2 & 12.6 & 9.4 & 1.8 & 0.75 & 0.24 \\
\hline Acetate/propionate & 1.61 & 1.53 & 1.63 & 0.17 & 0.95 & 0.68 \\
\hline Estimated methane $^{2}$ & 0.40 & 0.40 & 0.42 & 0.03 & 0.73 & 0.70 \\
\hline
\end{tabular}

DM, dry matter; SEM, standard error of the mean; VFA, volatile fatty acids.

${ }^{1}$ Measured at 4-h posprandium (morning meal).

${ }^{2}$ Estimated methane based on VFA molar proportions as mol/mol glucose equivalent fermented (Wolin, 1960).

Table 4. Influence of supplementation level of kaolinite clay on growth performance of feedlot steers

\begin{tabular}{|c|c|c|c|c|c|c|}
\hline \multirow{2}{*}{ Item } & \multicolumn{3}{|c|}{ Kaolinite level (\% diet DM) } & \multirow{2}{*}{ SEM } & \multicolumn{2}{|c|}{ p-value } \\
\hline & 0 & 1 & 2 & & Linear & Quadraticc \\
\hline Days on test & 308 & 308 & 308 & & & \\
\hline Pen replicates & 6 & 6 & 6 & & & \\
\hline \multicolumn{7}{|l|}{ Live weight $(\mathrm{kg})^{1}$} \\
\hline Initial & 132.4 & 132.3 & 132.5 & 0.86 & 0.97 & 0.92 \\
\hline Final $^{2}$ & 576.8 & 584.1 & 580.09 & 4.83 & 0.56 & 0.39 \\
\hline \multicolumn{7}{|l|}{ ADG (kg) } \\
\hline 1 to $112 \mathrm{~d}$ & 1.39 & 1.40 & 1.42 & 0.01 & 0.11 & 0.73 \\
\hline 112 to $224 \mathrm{~d}$ & 1.53 & 1.53 & 1.53 & 0.02 & 0.99 & 1.0 \\
\hline 224 to $308 \mathrm{~d}$ & 1.40 & 1.47 & 1.40 & 0.04 & 0.93 & 0.13 \\
\hline 1 to $308 \mathrm{~d}$ & 1.44 & 1.47 & 1.46 & 0.02 & 0.58 & 0.40 \\
\hline \multicolumn{7}{|l|}{ DMI (kg/d) } \\
\hline 1 to $112 \mathrm{~d}$ & 5.42 & 5.35 & 5.43 & 0.05 & 0.95 & 0.25 \\
\hline 112 to $224 \mathrm{~d}$ & 8.31 & 8.18 & 8.32 & 0.11 & 0.98 & 0.32 \\
\hline 224 to $308 \mathrm{~d}$ & 10.45 & 10.67 & 10.44 & 0.11 & 0.55 & 0.06 \\
\hline 1 to $308 \mathrm{~d}$ & 7.82 & 7.83 & 7.85 & 0.05 & 0.70 & 0.99 \\
\hline \multicolumn{7}{|l|}{ ADG/DMI (kg/kg) } \\
\hline 1 to $112 \mathrm{~d}$ & 0.257 & 0.262 & 0.263 & 0.002 & 0.59 & 0.377 \\
\hline 112 to $224 \mathrm{~d}$ & 0.184 & 0.187 & 0.184 & 0.002 & 0.97 & 0.222 \\
\hline 224 to $308 \mathrm{~d}$ & 0.135 & 0.138 & 0.134 & 0.003 & 0.87 & 0.349 \\
\hline 1 to $308 \mathrm{~d}$ & 0.185 & 0.187 & 0.186 & 0.001 & 0.62 & 0.205 \\
\hline \multicolumn{7}{|c|}{ Dietary NE (Mcal/kg) } \\
\hline \multicolumn{7}{|l|}{ Maintenance } \\
\hline 1 to $112 \mathrm{~d}$ & 2.06 & 2.09 & 2.10 & 0.01 & 0.08 & 0.38 \\
\hline 112 to $224 \mathrm{~d}$ & 2.18 & 2.21 & 2.19 & 0.02 & 0.62 & 0.23 \\
\hline 224 to $308 \mathrm{~d}$ & 2.12 & 2.13 & 2.11 & 0.03 & 0.97 & 0.64 \\
\hline 1 to $308 \mathrm{~d}$ & 2.15 & 2.18 & 2.16 & 0.02 & 0.58 & 0.21 \\
\hline \multicolumn{7}{|l|}{ Gain } \\
\hline 1 to $112 \mathrm{~d}$ & 1.40 & 1.43 & 1.43 & 0.01 & 0.08 & 0.38 \\
\hline 112 to $224 \mathrm{~d}$ & 1.50 & 1.53 & 1.51 & 0.02 & 0.62 & 0.23 \\
\hline 224 to $308 \mathrm{~d}$ & 1.45 & 1.46 & 1.44 & 0.03 & 0.97 & 0.64 \\
\hline 1 to $308 \mathrm{~d}$ & 1.47 & 1.50 & 1.48 & 0.01 & 0.58 & 0.21 \\
\hline \multicolumn{7}{|c|}{ Observed:expected dietary NE } \\
\hline \multicolumn{7}{|l|}{ Maintenance } \\
\hline 1 to $112 \mathrm{~d}$ & 0.93 & 0.96 & 0.97 & 0.006 & $<0.01$ & 0.41 \\
\hline 112 to $224 \mathrm{~d}$ & 0.99 & 1.01 & 1.01 & 0.008 & 0.03 & 0.24 \\
\hline 224 to $308 \mathrm{~d}$ & 0.96 & 0.98 & 0.98 & 0.014 & 0.32 & 0.66 \\
\hline 1 to $308 \mathrm{~d}$ & 0.97 & 1.00 & 1.00 & 0.007 & 0.07 & 0.22 \\
\hline \multicolumn{7}{|l|}{ Gain } \\
\hline 1 to $112 \mathrm{~d}$ & 0.91 & 0.95 & 0.96 & 0.008 & $<0.01$ & 0.41 \\
\hline 112 to $224 \mathrm{~d}$ & 0.98 & 1.02 & 1.02 & 0.011 & 0.03 & 0.24 \\
\hline 224 to $308 \mathrm{~d}$ & 0.95 & 0.97 & 0.97 & 0.018 & 0.33 & 0.66 \\
\hline 1 to $308 \mathrm{~d}$ & 0.97 & 1.00 & 1.00 & 0.009 & 0.07 & 0.22 \\
\hline
\end{tabular}

DM, dry matter; SEM, standard error of the mean; ADG, average daily gain; DMI, dry matter intake; NE, net energy.

${ }^{1}$ Initial weight is the shrunk off truck arrival weight. Interim and final weights were reduced $4 \%$ to account for digestive tract fill.

${ }^{2}$ Final shrunk weight was adjusted for carcass weight by dividing the carcass weight by the decimal fraction of the average dressing percentage ( 0.618 ). 
Table 5. Influence of supplementation level of kaolinite clay on carcass characteristics of Holstein steers

\begin{tabular}{|c|c|c|c|c|c|c|}
\hline \multirow{2}{*}{ Item } & \multicolumn{3}{|c|}{ Kaolinite level (\% diet DM) } & \multirow{2}{*}{ SEM } & \multicolumn{2}{|c|}{ Contrast p-value } \\
\hline & 0 & 1 & 2 & & Linear & Quadratic \\
\hline Pen replicates & 6 & 6 & 6 & & & \\
\hline Hot carcass weight (kg) & 356.25 & 360.8 & 358.8 & 3.0 & 0.56 & 0.39 \\
\hline Dressing percentage & 62.1 & 61.8 & 61.4 & 0.2 & 0.01 & 0.90 \\
\hline Longissimus area $\left(\mathrm{cm}^{2}\right)$ & 77.6 & 80.4 & 79.9 & 2.8 & 0.56 & 0.64 \\
\hline Fat thickness $(\mathrm{cm})$ & 0.76 & 0.89 & 0.82 & 0.04 & 0.35 & 0.07 \\
\hline KPH (\%) & 2.43 & 2.39 & 2.45 & 0.05 & 0.77 & 0.45 \\
\hline Yield grade $(\%)^{1}$ & 51.8 & 52.1 & 52.0 & 0.3 & 0.64 & 0.72 \\
\hline Quality grade ${ }^{2}$ & 4.93 & 5.08 & 4.73 & 0.22 & 0.52 & 0.37 \\
\hline
\end{tabular}

DM, dry matter; SEM, standard error of the mean; KPH, kidney, pelvic and heart fat; LM, lgissimus.

${ }^{1}$ Kidney, pelvic, and heart fat as a percentage of carcass weight.

${ }^{2}$ Assessment of external 12th-rib fat thickness, KPH, LM area, lean and skeletal maturity, lean color, and marbling were used to determine a quality and yield grade for each carcass (USDA, 1997).

on ADG, and gain efficiency (ADG/DMI). Effects of clay inclusion on DMI and ADG in growing-finishing ruminants has not been consistent. Colling et al. (1979) observed decreased ADG and DMI in finishing steers fed highmoisture and steam-flaked corn-based diets supplemented with $2.5 \%$ bentonite. In other studies (Cammack et al., 2010), supplementation with $2 \%$ to $5 \%$ clay (as bentonite or zeolite) did not affect ADG, or gain efficiency. Mendel (1971) did not detect differences in DMI between controls and supplemented steers fed $2 \%$ to $4 \%$ montmorillonite clay. However, ADG was $8.9 \%$ and $13.2 \%$ greater with $2 \%$ and $4 \%$ supplemental montmorillonite, respectively. Berthiaume et al. (2007) observed greater ADG in steers supplemented with $2 \%$ bentonite in a silage-based diet.

Kaolinite supplementation tended (linear effect, $p=0.08$ ) to increase dietary NE during the initial 112-d period. However, the overall (308-d) effect of supplementation on dietary NE was not appreciable ( $>00.20)$. Kaolinite replaced steam-flaked corn in the basal diet (Table 1). Considering the indigestibility of kaolinite (contains no $\mathrm{OM}$ ), the ratio of observed-to-expected dietary NE increased with kaolinite supplementation. This effect was more pronounced (linear effect, $\mathrm{p} \leq 0.03$ ) during the initial $224 \mathrm{~d}$ of the study. Overall (308 d), kaolinite supplementation tended to increase (linear effect, $\mathrm{p}=0.07$ ) dietary NE by $3 \%$ over expected. Based on the apparent absence of effects of supplemental kaolinite on ruminal and total tract digestion, and ruminal fermentation parameters, the positive effect of clay on the dietary energetic may operate in a manner independent of changes in characteristics of ruminal and total tract digestion. However, increases on feed efficiency have been observed in lambs and steers fed diets supplemented with bentonite (Britton et al., 1978).

The effects of supplemental kaolinite on carcass characteristics are shown in Table 5. As expected, there were no treatment effects on $\mathrm{HCW}$, yield grade, LM area, KPH, and quality grade. Kaolinite supplementation linearly decreased $(p<0.01)$ dressing percentage. The negative effect of supplemental kaolinite on dressing percentage could be more apparent than real. It has been argued that clay essentially is not absorbed and is excreted with the feces. Because of its density, it is reasonable that the clay particles would accumulate along the digestive tract, particularly in the forestomach regions.

It is concluded that kaolinite supplementation up to $2 \%$ of diet DM may enhance energetic efficiency of calf-fed Holstein steers in a manner independent of changes in characteristics of ruminal and total tract digestion.

\section{CONFLICT OF INTEREST}

We certify that there is no conflict of interest with any financial organization regarding the material discussed in the manuscript.

\section{REFERENCES}

AOAC (Association Official Analytical Chemists). 2000. Official methods of analysis. 17th edn. Association Official Analytical Chemists. Gaithersburg, MD, USA.

Bergen, W. G., D. B. Purser, and J. H. Cline. 1968. Effect of ration on the nutritive quality of rumen microbial protein. J. Anim. Sci. 27:1497-1501.

Berthiaume, R., M. Ivan, and C. Lafreniere. 2007. Effects of sodium bentonite supplements on growth performance of feedlot steers fed direct-cut or wilted grass silage based diets. Can. J. Anim. Sci. 87:631-638.

Britton, R. A., D. P. Cooling, and T. J. Klopfenstein. 1978. Effect of complexing sodium bentonite with soybean meal or urea in vitro ruminal ammonia release and nitrogen utilization in ruminants. J. Anim. Sci.46:1738-1747.

Cammack, K. M., C. L.Wright, K. J. Austin, P. S. Johnson, R. R. Cockrum, K. L. Kessler, and K. C. Olson. 2010. Effects of highsulfur water and clinoptilolite on health and growth performance of steers fed forage-based diets. J. Anim. Sci. 88:1777-1785. 
Cole, N. A., R. W. Todd, and D. B. Parker. 2007. Use of fat and zeolite to reduce ammonia emissions from beef cattle feedyards. In: Proceedings of the Air Quality Waste Management Agriculture. Broomfield, CO, USA; ASABE Publication Number 701P0907cd.

Colling, D. P., R. A. Britton, S. D. Farlin, and M. K. Nielsen. 1979. Effects of adding sodium bentonite to high grain diets for ruminants. J. Anim. Sci. 48:641-648.

Dinius, D. A., A. D. Peterson, T. A. Long, and B. R. Baumgardt. 1970. Intake and digestibility by sheep or rations containing various roughage substitutes. J. Anim. Sci. 30:309-312.

EFSA (European Food Safety Authority). 2016. Safety and efficacy of a natural mixture of illite, montmorillonite and kaolinite (Argile Verte du Velay) as a feed additive for all animal species. EFSA J. 14:4342-4360.

Garrett, W. N. 1971. Energetic efficiency of beef and dairy steers. J. Anim. Sci. 32:451-456.

Hill, F. N. and D. L. Anderson. 1958. Comparison of metabolizable energy and productive energy determinations with growing chicks. J. Nutr. 64:587-603.

Ivan, M., M. S. Dayrell, and M. Hidiroglou. 1992. Effects of bentonite and monensin on selected elements in the stomach and liver of fauna-free and faunated sheep. J. Dairy Sci. 75:201-208.

Martin, L. C., A. J. Clifford, and A. D. Tillman. 1969. Studies on sodium bentonite in ruminant diets containing urea. J. Anim. Sci. 29:777-782

McCollum, F. T. and M. L. Galyean. 1983. Effects of clinoptilolite on rumen fermentation, digestion and feedlot performance in beef steers fed high concentrate diets. J. Anim. Sci. 56:517-524.

Mendel, V. E. 1971. Montmorillonite clay in feed lot rations. J. Anim. Sci. 33:891-894.

Murphey, C. E., D. K. Hallett, W. E. Tyler, and J. C. Pierce Jr. 1960. Estimating yields of retail cuts from beef carcasses. In: the 62nd Meeting of the American Society of Animal Production, Chicago, IL, USA. pp. 1-12.

NRC (National Research Council). 1984. Nutrient Requirements of Beef Cattle. 6th edn. National Academy of Press, Washington, DC, USA.

NRC (National Research Council). 1996. Nutrient Requirements of Beef Cattle. 7th edn. National Academy of Press, Washington, DC, USA.
Orskov, E. R., N. A. MacLeod, and D. J. Kyle. 1986. Flow of nitrogen from the rumen and abomasum in cattle and sheep given protein-free nutrients by intragrastric infusion. Br. J. Nutr.56:241-248.

Owen, O. J., M. B. Nodu, U. A. Dike, and H. M. Ideozu. 2012. The effect of dietary kaolin (clay) as feed additive on the growth performance of broiler chickens. Greener J. Agric. Sci. 6:233236.

Safaei, M., F. Boldaji, B. Dastar, S. Hassani, M. S. A. Mutalib, and R. Rezaei. 2014. Effects of inclusion kaolin, bentonite and zeolite in dietary on chemical composition of broiler chicken meat. Asian J. Anim. Vet. Adv. 9:56-63.

SAS (Statistical Analysis System) Institute Inc. 2004. User's Guide: Statistics, version 9. SAS Inst. Cary, NC, USA.

Spotti, M., M. L. Fracchiola, F. Arioli, F. Canoni, and G. Pompa. 2005. Aflatoxin $\mathrm{B}_{1}$ binding to sorbents in bovine ruminal fluid. Vet. Res. Commun. 29: 507-515.

Tate, K., G. Youan, B. Theng, G. Churchman, J. Sing, and P. Berben. 2015. Can geophagy mitigate enteric methane emission from cattle? J. Prelim. Res. 2:1-8.

Trckova, M., L. Matlova, L. Dvorska, and I. Pavlik. 2004. Kaolin, bentonite and zeolites as feed supplements for animals: health advantages and risks. Vet. Med. Czech. 49:389-399.

USDA (United States Department of Agriculture). 1997. United States Standards for Grading of Carcass Beef. Agricultural Marketing Service, USDA Washington, DC, USA.

Van Soest, P. J., J. B. Robertson, and B. A. Lewis. 1991. Methods for dietary fiber, neutral detergent fiber, and nonstarch polysaccharides in relation to animal nutrition. J. Dairy Sci. 74:3583-3597.

Wolin, M. J. 1960. A theoretical rumen fermentation balance. J. Dairy Sci. 43:1452-1459.

Zinn, R. A. 1990. Influence of flake density on the comparative feeding value of steam-flaked corn for feedlot cattle. J. Anim. Sci. 68:767-775.

Zinn, R. A. and F. N. Owens. 1986. A rapid procedure for purine measurement and its use for estimating net ruminal protein synthesis. Can. J. Anim. Sci. 66:157-166.

Zinn, R. A., A. Barreras, F. N. Owens, and A. Plascencia. 2008. Performance by feedlot steers and heifers: daily gain, mature weight, dry matter intake and dietary energetics. J. Anim. Sci. $86: 2680-2689$ 